\title{
On the Reliability of International Forest Sector Statistics: Problems and Needs for Improvements
}

\author{
A. Maarit I. Kallio 1,* (D) and Birger Solberg ${ }^{2}$ \\ 1 Bioeconomy and Environment, Natural Resources Institute Finland, Latokartanonkaari 9, \\ 00790 Helsinki, Finland \\ 2 Faculty of Environmental Sciences and Natural Resource Management, Norwegian University of Life \\ Sciences, Universitetstunet 3, 1433 Ås, Norway; birger.solberg@nmbu.no \\ * Correspondence: a.maarit.i.kallio@luke.fi; Tel.: +358-295-325-434
}

Received: 6 June 2018; Accepted: 3 July 2018; Published: 5 July 2018

\begin{abstract}
Statistics on production and trade of forest products form a basis for the analyses of the economic and environmental performance of the forest sector and for projecting future developments in the sector and related markets. The forest product statistics FAOSTAT by Food and Agriculture Organization of the United Nations (FAO) are perhaps the most widely used data source for such analyses. This study aimed at systematically scrutinizing this important dataset and identifying regions and product categories where improved data on wood and forest industry production and trade would be needed in order to set the modeling and analyses employing these data on a more solid basis. The consistency of the data on production, imports, and export volumes of wood was examined with some simple tests and with the aid of linear programming. The results show that the data related to the supply of wood chips and particles are unreliable in many countries. Improving these data would be important in order to assess the cascading wood input-output flows, to evaluate resource potentials, and to specify more reliable coefficients for wood use in forest sector models. Moreover, the data show remarkable inconsistencies, even of the magnitude of millions of cubic meters, between the apparent supply of wood (harvests + net imports) and forest industry production in many regions. Errors and uncertainties of such magnitude have important consequences on the results of any analysis using the data and call for special attention by the data users.
\end{abstract}

Keywords: data; errors; forest products; forestry; statistics; FAOSTAT; modeling

\section{Introduction}

The forest product statistics FAOSTAT of Food and Agriculture Organization of the United Nations (FAO) on the production and trade of wood and wood products [1] provide an important and valuable basis for the economic and environmental analyses and projections of the developments in the forest sector. Consequently, these statistics are employed for various sectoral analyses using partial economic equilibrium models, such as the global forest product model (GFPM [2]), the global forest sector model EFI-GTM (e.g., [3]), the global biosphere management model (GLOBIOM [4]), and many others. Typically, the FAOSTAT data are used for defining wood harvest volumes and apparent consumption levels for the forest industry products for the first period modeled (base year) in such models. Depending on the model, the FAOSTAT data may also be employed, for instance, to define inertia constraints for the trade in forest products, to define the base year production capacities for the forest industry, and to calibrate the wood-input coefficients and production costs for the forest industry. Furthermore, many other prognoses and analyses $([5,6])$ concerning consumption and the markets for forest products are based on these data. Among the various other research purposes, the data have been used to support studies on carbon dynamics in wood products [7], the water footprint of forest 
products [8], the forest footprint of the European Union [9], and the role of trade in deforestation [10], to name but a few examples of the recent studies. The FAOSTAT data could also be useful for the Intergovernmental Panel on Climate Change (IPCC) for tracking the production, trade, and apparent consumption of harvested wood products and roundwood [11] and for the development of climate change mitigation policies (e.g., [11,12]).

The reliability of these data is thus of crucial importance. This study aims at systematically scrutinizing them and identifying the most important product groups and geographical areas where improvements would be required to set the modeling, analyses, and forecasting of the forest sector on more solid ground. The data on production, imports, and export quantities are explored first with some simple tests and then with the aid of linear programming (LP). In the latter case, it is tested if it is possible to find reasonable wood input coefficients for various industrial products so that the volume of wood biomass available according to the statistics has been adequate to supply the raw material needs for the reported production quantities in the forest industries. The tests identify considerable inconsistencies in the data for several countries.

\section{Material and Methods}

\subsection{Data}

\subsubsection{Data on Production and Trade}

The main data source and also the subject for our analysis was the FAOSTAT forestry database. In addition, the United Nations Economic Commission for Europe (UNECE)-FAO production statistics [13] were used to gain information on the division of plywood production to softwood and hardwood grades in the countries within the domain of those statistics. The data in FAO pulp and paper production capacity surveys from the year 2000 onwards [14] were used as an aid to divide sulfate pulp production to softwood and hardwood grades, though these data do not seem to cover all countries. For pulp production, data from RISI [15] were also available, but because this dataset is not available for free, its use was limited here to inform if a country only produced hardwood or softwood sulfate pulp.

Table 1 presents the products considered and the sources for the data on production and trade that were already available or estimated within this study using linear programming.

In the FAOSTAT data, the category "wood chips and particles" includes wood reduced to small pieces, which issuitable for pulping, particle board or fiberboard production, and wood for use as a fuel or other purposes. It excludes wood chips made directly in the forest from roundwood. The category "wood residues" includes wood processing co-products other than those belonging to wood chips and particles, such as sawmill rejects, slabs, edgings and trimmings, veneer log cores, veneer rejects, sawdust, residues from carpentry and joinery production, and wood residues that will be used for production of pellets and other agglomerated products.

Table 1. Annual production and trade data used. $\mathrm{D}=$ Data given in FAO forest product statistics (FAOSTAT [1]), U = data given in UNECE/FAO [13] for Europe and North America, e = data estimated based on the other data using linear programming. $\mathrm{C}=$ coniferous, $\mathrm{NC}=$ non-coniferous, $\mathrm{Sa}=$ sulfate, $\mathrm{Si}$ = sulfite, $\mathrm{Bl}=$ bleached, $\mathrm{Unbl}=$ unbleached. UNECE $/ \mathrm{FAO}$, the United Nations Economic Commission for Europe-The Food and Agriculture Organization of the United Nations.

\begin{tabular}{|c|c|c|c|c|}
\hline Product & Product & Production & Imports & Exports \\
\hline Industrial roundwood C & & $\mathrm{D}$ & $\mathrm{D}$ & $\mathrm{D}$ \\
\hline & Sawlogs and veneer logs C & $\mathrm{D}$ & $\mathrm{e}$ & $\mathrm{e}$ \\
\hline & Pulpwood C & $\mathrm{D}$ & $\mathrm{e}$ & e \\
\hline & Other industrial roundwood C & $\mathrm{D}$ & $\mathrm{e}$ & $\mathrm{e}$ \\
\hline Industrial roundwood NC & & $\mathrm{D}$ & $\mathrm{D}$ & $\mathrm{D}$ \\
\hline
\end{tabular}


Table 1. Cont.

\begin{tabular}{|c|c|c|c|c|}
\hline Product & Product & Production & Imports & Exports \\
\hline & $\begin{array}{l}\text { Industrial roundwood NC, } \\
\text { non-tropical }\end{array}$ & & $\mathrm{D}$ & $\mathrm{D}$ \\
\hline & Industrial roundwood NC, tropical & & $\mathrm{D}$ & $\mathrm{D}$ \\
\hline & Sawlogs and veneer logs NC & $\mathrm{D}$ & e & e \\
\hline & Pulpwood NC & $\mathrm{D}$ & $\mathrm{e}$ & $\mathrm{e}$ \\
\hline & Other industrial roundwood NC & $\mathrm{D}$ & e & $\mathrm{e}$ \\
\hline Wood residues & & $\mathrm{D}$ & $\mathrm{D}$ & $\mathrm{D}$ \\
\hline & Wood residues $C$ & $\mathrm{e}$ & & \\
\hline & Wood residues NC & e & & \\
\hline Chips and particles & & $\mathrm{D}$ & $\mathrm{D}$ & $\mathrm{D}$ \\
\hline & Chips and particles $C$ & $\mathrm{e}$ & e & e \\
\hline & Chips and particles NC & $\mathrm{e}$ & e & e \\
\hline Pellets & & $\mathrm{D}$ (since 2012) & & \\
\hline Chemical pulp & & $\mathrm{D}$ & & \\
\hline & Dissolving pulp & $\mathrm{D}$ & & \\
\hline & Chemical wood pulp Sa Unbl & $\mathrm{D}$ & & \\
\hline & Chemical wood pulp Sa Bl & $\mathrm{D}$ & & \\
\hline & -Bleached hardwood kraft & $\mathrm{e}$ & & \\
\hline & -Bleached softwood kraft & e & & \\
\hline & Chemical wood pulp Si Unbl & $\mathrm{D}$ & & \\
\hline & Chemical wood pulp Si Bl & $\mathrm{D}$ & & \\
\hline Semichemical pulp & & $\mathrm{D}$ & & \\
\hline Mechanical pulp & & $\mathrm{D}$ & & \\
\hline Sawnwood C & & $\mathrm{D}$ & & \\
\hline Sawnwood NC & & $\mathrm{D}$ & & \\
\hline Plywood and veneer & & $\mathrm{D}$ & & \\
\hline & Plywood and veneer $C$ & $\mathrm{e}, \mathrm{U}$ & & \\
\hline & Plywood and veneer NC & e, $U$ & & \\
\hline Particleboard & & $\mathrm{D}$ & & \\
\hline OSB (Oriented strand board) & & D (since 1995) & & \\
\hline $\begin{array}{l}\text { MDF (Medium-density fibreboard)/ } \\
\text { HDF (High-density fibreboard) }\end{array}$ & & $\mathrm{D}$ & & \\
\hline Hardboard & & $\mathrm{D}$ & & \\
\hline Fiberboard & & $\mathrm{D}$ & & \\
\hline
\end{tabular}

\subsubsection{Data on Conversion Factors Used in LP Test}

Here, the term conversion factor refers to an input quantity of roundwood, wood residues, or chips and particles in solid cubic meters $\left(\mathrm{m}^{3}\right)$ under bark needed to produce one cubic meter of mechanical forest industry product or 1 tonne of pulp. The assumptions made regarding the possible uses of different wood categories within the forest industry are given in Table 2.

The main references for the conversion factors were the UNECE and the European Forest Sector Outlook Study 2005 [16-18]. Table 2 summarizes the conversion factors, while any available country specific conversion factors used are provided in the Supplementary Materials (Supplementary File S1: Data for reference input coefficients (excel-file)). 
Table 2. Wood categories suitable as inputs in forest industry products and the assumed typical (Ref), low (Ref low), and high (Ref high) wood input quantities in the linear programming (LP) test when country-specific reference quantities were not available. Min and Max in the parentheses are additional broader minimum and maximum input quantities applied for all regions, respectively. Slogs $=$ sawlogs and veneer logs, Pwd = pulpwood, Res = wood residues, Chips $=$ chips and particles, $\mathrm{C}=$ coniferous, and NC = non-coniferous. Sources: $\mathrm{a}=$ The smallest value given in UNECE [18] (after Spain and Portugal with $1.2 \mathrm{~m}^{3} / \mathrm{m}^{3}$ for veneer sheets removed from the sample); $b=$ Average of all values in [18]; and c = the highest value in [18]. If data were not available from [18] for (a), (b), or (c), data from [16] were used.

\begin{tabular}{|c|c|c|c|c|}
\hline Forest Industry Product & $\begin{array}{c}\text { Ref Low (Min), } \mathrm{m}^{3} \text { of } \\
\text { Wood per Unit of Output }\end{array}$ & $\begin{array}{l}\text { Ref Typical, } \mathrm{m}^{3} \text { of Wood } \\
\text { per Unit of Output }\end{array}$ & $\begin{array}{c}\text { Ref High (Max), } \mathrm{m}^{3} \text { of } \\
\text { Wood per Unit of Output }\end{array}$ & Wood Categories Suitable as Inputs \\
\hline Chemical wood pulp Si Un bl. & $4.6(4.0)$ & 4.5 & $6.0(6.0)$ & Pwd (C, NC), Chips (C, NC) \\
\hline Chemical wood pulp Sa Un bl. & $3.5(3.2)$ & 4.3 & $5.0(5.5)$ & Pwd (C, NC), Chips (C, NC) \\
\hline Chemical wood pulp Sa Bl. & $3.5(2.98)$ & 4.5 & $5.5(6.5)$ & Pwd (C, NC), Chips (C, NC) \\
\hline Bleached hardwood kraft & $3.5(2.98)$ & 3.8 & $4.3(5)$ & Pwd (NC), Chips (NC) \\
\hline Bleached softwood kraft & $4.5(4.79)$ & 4.9 & $5.3(6.5)$ & Pwd (C), Chips (C) \\
\hline Dissolving pulp & $5.1(5.0)$ & $5.65 \mathrm{~b}$ & $6.5(6.8)$ & Pwd (C, NC), Chips (C, NC) \\
\hline Mechanical pulp & $2.4(2.3 \mathrm{a})$ & $2.5 \mathrm{~b}$ & $2.9(2.9 \mathrm{c})$ & Pwd (C), Chips (C) \\
\hline Sawnwood C & $1.6(1.42 \mathrm{a})$ & $1.77 \mathrm{~b}$ & $2.0(2.22 \mathrm{c})$ & Slogs $(\mathrm{C})$ \\
\hline Sawnwood NC & $1.5(1.4 \mathrm{a})$ & $1.76 \mathrm{~b}$ & $2.1(2.5 \mathrm{c})$ & Slogs (NC) \\
\hline Plywood and veneer sheets & $1.7(1.67 \mathrm{a})$ & $2.19 \mathrm{~b}$ & $2.5(3.1 \mathrm{c})$ & Slogs (C), Slogs (NC) \\
\hline Plywood and veneer C & $1.9(1.67 \mathrm{a})$ & $2.0 \mathrm{~b}$ & $2.31(2.9 \mathrm{c})$ & Slogs $(\mathrm{C})$ \\
\hline Plywood and veneer NC & $2.0(1.67 \mathrm{a})$ & $2.29 \mathrm{~b}$ & $2.68(3.1 \mathrm{c})$ & Slogs (NC) \\
\hline Particleboard & $1.4(1.2 \mathrm{a})$ & $1.49 \mathrm{~b}$ & $1.7(1.93 \mathrm{c})$ & Pwd $(C, N C)$, Chips $(C, N C), \operatorname{Res}(C, N C)$ \\
\hline OSB & $1.4(1.30 \mathrm{a})$ & $1.64 \mathrm{~b}$ & $2.0(2.0 \mathrm{c})$ & Pwd (C, NC), Chips (C, NC), Res (C, NC) \\
\hline $\mathrm{MDF} / \mathrm{HDF}$ & $1.5(1.45 \mathrm{a})$ & $1.68 \mathrm{~b}$ & $1.8(1.93 \mathrm{c})$ & Pwd $(C, N C)$, Chips $(C, N C)$, Res (C, NC) \\
\hline Fiberboard & $1.7(1.5 \mathrm{a})$ & $1.98 \mathrm{~b}$ & $2.8(3.0 \mathrm{c})$ & Pwd $(C, N C)$, Chips $(C, N C)$, Res $(C, N C)$ \\
\hline Pellets & $2.3(2.2 \mathrm{a})$ & $2.54 \mathrm{~b}$ & $2.9(3.0)$ & $\operatorname{Res}(\mathrm{C}, \mathrm{NC})$ \\
\hline
\end{tabular}




\subsection{Methods Used to Analyze the Data}

\subsubsection{Simple Tests with the Raw Data}

First, the regional data on the production and trade of industrial roundwood, wood residues, chips, and particles were examined with three relatively simple tests i-iii, described below under the questions (i)-(iii), respectively.

(i) Is the reported wood production at least as high as the reported net export (exports - imports)? If not, the region's apparent wood consumption is negative, which signals errors in the underlying data.

The data allowed this first infeasibility check to be made for four wood categories: industrial coniferous roundwood, industrial non-coniferous roundwood, chips and particles, and wood residues.

(ii) Is the reported production of chips, particles, and wood residues (too) high compared to the production of solid wood products?

This test identifies countries where the produced number of woody by-products is considerably higher than the produced amount of the solid wood products. The test was carried out for the category of "wood chips and particles" alone and then for the total amount of by-products labeled "wood chips and particles" and "wood residues".

If the number of by-products is much higher than the production of the principal products, there is probably something wrong in the data, despite the fact that part of the residues comes from further processing of sawnwood, veneer, and plywood to finished products, carpentry, and so on.

Typically, chips and particles are obtained as a side product of sawnwood and plywood production, and they form only part of the material obtained as by-products. Also, other types of residues, for instance sawdust, are coming out. Moreover, part of the log input in sawnwood and plywood production vanishes due to shrinking. The log input coefficient under bark in the production of solid wood products is seldom above 2 (Table 2), in particular, when it comes to sawnwood that is more commonly produced than plywood and veneer. For these reasons, it is reasonable to expect that production of chips and particles should not exceed that of solid wood products. If the output of "chips and particles" and solid wood products were equal, it would indicate that little other material would come out from the process.

(iii) Are the apparent levels of wood use high enough for the reported production of forest industry products?

This test was done for all sawlogs and veneer logs (coniferous + non-coniferous), for pulpwood and pulpwood substitutes (coniferous pulpwood + non-coniferous pulpwood + chips and particles), and for all wood. If the assumed required minimum consumption of wood inputs exceeds the amount of their maximum availability under the rather loose requirements discussed below, it is likely that there is something wrong with the data.

\section{- Case of sawlogs and veneer logs used for sawnwood, plywood, and veneer}

In this test, the assumed minimum quantity of logs needed in sawnwood, veneer, and plywood production in a country was compared to the maximum potential volume of sawlogs and veneer logs available based on the statistics on wood harvest and trade. The test setting was cautious for the following reasons. Firstly, it was assumed that $1.5 \mathrm{~m}^{3}$ of logs under bark are sufficient to produce one unit of sawnwood, veneer, or plywood. This coefficient can be considered somewhat low (see Table 2). Secondly, the maximum available amount of sawlogs and veneer logs in a region was defined to include sawlog and veneer logs harvests and all industrial roundwood imports to the country, despite the fact that part of the imports can be pulpwood or roundwood for other industrial uses. Thirdly, all the exports of industrial roundwood were assumed to consist of the wood grades other than sawlogs and veneer logs. 


\section{- Case of wood material used for pulp}

This test asked if there may have been enough pulpwood, chips, and particles to sustain the reported wood pulp production in a country. Again, the test was rather robust in the sense that the requirements for the data passing the test were set low. It was assumed that all pulpwood, chips, and particles potentially available in a region may have been used for pulp production, although these raw materials are also used for particle board, Medium-density fibreboard (MDF), and other panel products. Furthermore, all industrial roundwood imports were now assumed to be pulpwood, while all roundwood exports were assumed to be other wood grades. It was modestly assumed that chemical pulp requires only $3 \mathrm{~m}^{3}$, dissolving pulp $4 \mathrm{~m}^{3}$ and mechanical and semi-chemical pulp $2 \mathrm{~m}^{3}$ of wood fiber per tonne of pulp output.

- Case of all wood materials used for all products

This test added panels (particle board, Oriented strand board (OSB), MDF, etc.) to the previous set of products and asked whether the production of this new set of products could have been produced by the wood material reported to be available. a very modest (see Table 2) wood use coefficient was applied to these panels: $1 \mathrm{~m}^{3} / \mathrm{m}^{3}$. For the other products, the minimum input coefficients described above were used. "Wood residues" were included to the available wood together with sawlogs, pulpwood, chips, and particles. The amount of wood available per country was defined to include net imports (imports - exports) and own harvests or production of these wood grades. The test compared only the total wood material reported to be available in a region to the conservatively defined aggregated demand for wood materials in the reported forest industry productions. It imposed no allocation rules based on the suitability of alternative wood grades (Table 2) to different products.

\subsubsection{Test Using Linear Programming}

An LP formulation was used to improve the consistency and precision of test iii for all wood grades and products and also to identify the cases where the regional wood supply seems too high compared to the respective forest industry production. Because the exact mathematical formulation of the LP problem is space demanding, only its main principles are described here, while a complete description, including all the constraints, is provided in the Supplementary File S2: Description of the LP model (word.doc).

The main principle of the LP program is that it aims to find input coefficients for the industrial products in Table 1 that are as close as possible to the reference values given in Table 2 (or the more country-specific figures) and which, when applied to the reported forest industry production data, match the consumption of various wood grades to their apparent availability (production + imports exports) as well as possible. The objective function minimizes the sum of the various penalty variables that allow the data to be inconsistent with the rules defined.

Three levels of penalty variables for the wood input coefficients not complying with their reference values were defined: (1) a somewhat low penalty of deviation from the point estimate reference value; (2) a higher penalty for input coefficients not being within an assumed range around the reference value; and (3) the highest penalty for not even fitting in between the absolute minimum and maximum values defined for the coefficients. The default input coefficient values are given in Table 2 but were refined as shown in the Supplementary Materials when there was additional country-specific information available. When looking for the input coefficients, constraints (subject to penalty variables if violated) that aim to minimize year-to-year fluctuations of the input coefficients were also defined so that the technologies were assumed to be material saving. a regional input coefficient for a product in a given year that was higher than that in the previous year was penalized if there was production in both years.

Roundwood harvests were constrained to equal the harvests reported in the statistics subject to penalty variables. The calculated value for the penalty variable in a region indicated the suggested deviation from roundwood harvests from the statistics. 
The program also divided the traded quantities of roundwood given in the statistics between pulpwood, sawlogs, and other industrial wood. It also divided the production of sulfate pulp, plywood and veneer, and chips and particles into coniferous and non-coniferous grades. These divisions were done so that the data become as consistent as possible with the wood use in the forest industry.

Before doing the LP test, the data showing negative apparent consumption figures for wood in test $\mathrm{i}$ described in Section 2.2.1 were modified as follows:

- The production volumes of wood residues and chips were increased to match with the exports.

- The production volumes of other coniferous or other non-coniferous industrial roundwood were increased if the apparent consumption of coniferous or non-coniferous roundwood was negative, respectively. Such typically small adjustments were rarely needed.

Similarly, noting the inconsistencies raised by test ii, the following modifications for the data on by-product outputs were made before the LP test in order to improve their consistency with the production of the solid wood products (sawnwood, plywood, and veneer).

- The production volumes for chips and particles were decreased to be at most $80 \%$ of the production of solid wood products.

- The production of wood residues was reduced, if necessary, so that the resulting logs input calculated as "(sawnwood production + plywood and veneer production + chips and particles production + wood residues production)/(sawnwood production + plywood and veneer production)" is at most $2.8 \mathrm{~m}^{3} / \mathrm{m}^{3}$. If a country then violated test $i$, the exports were reduced.

Test $\mathrm{i}$ in Section 2.2.1 mostly identified cases where the production of forest industry residues was too low compared to the exports, while test ii found cases where it was too high, generally. Consequently, further corrections made based on test ii seldom affected the same countries.

\section{Results}

\subsection{Test $i$ : Is the Apparent Wood Consumption Non-Negative?}

Table 3 shows the data for countries that had an apparent consumption figure of more than $5000 \mathrm{~m}^{3}$ negative in 2015 for the four wood categories tested. The dataset for the cases for such negative apparent consumption figures during a longer period 2000-2016 is given in the Supplementary File S3: Additional results from the tests (excel-file).

The problem of data indicating negative consumption levels is mostly related to the category of "chips and particles". a negative apparent consumption of industrial roundwood occurs only with a few countries during 2000-2016. During the years of that period, only two to four countries out of the 244 tested had an apparent consumption figure of less than $-5000 \mathrm{~m}^{3}$ for coniferous industrial roundwood and at most two countries for non-coniferous roundwood. The figures of Costa Rica and Myanmar for coniferous roundwood were negative for most of this period. These countries report exports of coniferous wood but no production or imports. In 2015-2016, New Zealand reported negative apparent consumption for non-coniferous roundwood. For "wood residues", the number of respective annual observations with negative apparent consumption figures varied from one to eight during 2000-2016, while for "chips and particles" sometimes up to 18 countries reported data that indicate negative apparent consumption.

The problems of negative consumption figures for wood residues, chips, and particles are typically related to the issue that exports are reported, but data on production or imports are lacking. Some problems seem to relate to the lack of updates in the dataset. For instance, the production data for chips and particles for Indonesia and Fiji have obviously not been updated since 2011 (data status "FAO estimate"), while the respective data on exports have been revised annually (data status "FAO official").

The highest negative apparent consumption figure in 2015 for "chips and particles" is found for Vietnam $\left(-10 \mathrm{Mm}^{3}\right)$. The production of chips and particles in Vietnam has in the recent years reported (data status "FAO estimate") to be constant at $3.3 \mathrm{Mm}^{3}$, while the export volumes of over $12 \mathrm{Mm}^{3}$ have 
been reported (under data status "FAO official" or "FAO unofficial"). At the same time, the sawnwood and plywood production needed to give chips and particles as by-product has not been updated, and it has been reported to be below $8 \mathrm{Mm}^{3}$ (under data status "FAO official" or "FAO unofficial"). Considerable gaps in the net exports and production figures of chips and particles in 2015 are also given (e.g., for Gambia, Indonesia, Mozambique, Singapore, South Africa, and Thailand) as can be seen in Table 3.

Table 3. Annual productions, exports, imports, and apparent consumption of industrial roundwood and wood residues in 2015 and in the period of 2011-2015 on average $\left(1000 \mathrm{~m}^{3}\right)$. Only countries where apparent consumption in 2015 was $<-5000 \mathrm{~m}^{3}$ are shown. $\mathrm{C}=$ coniferous, $\mathrm{NC}=$ non-coniferous.

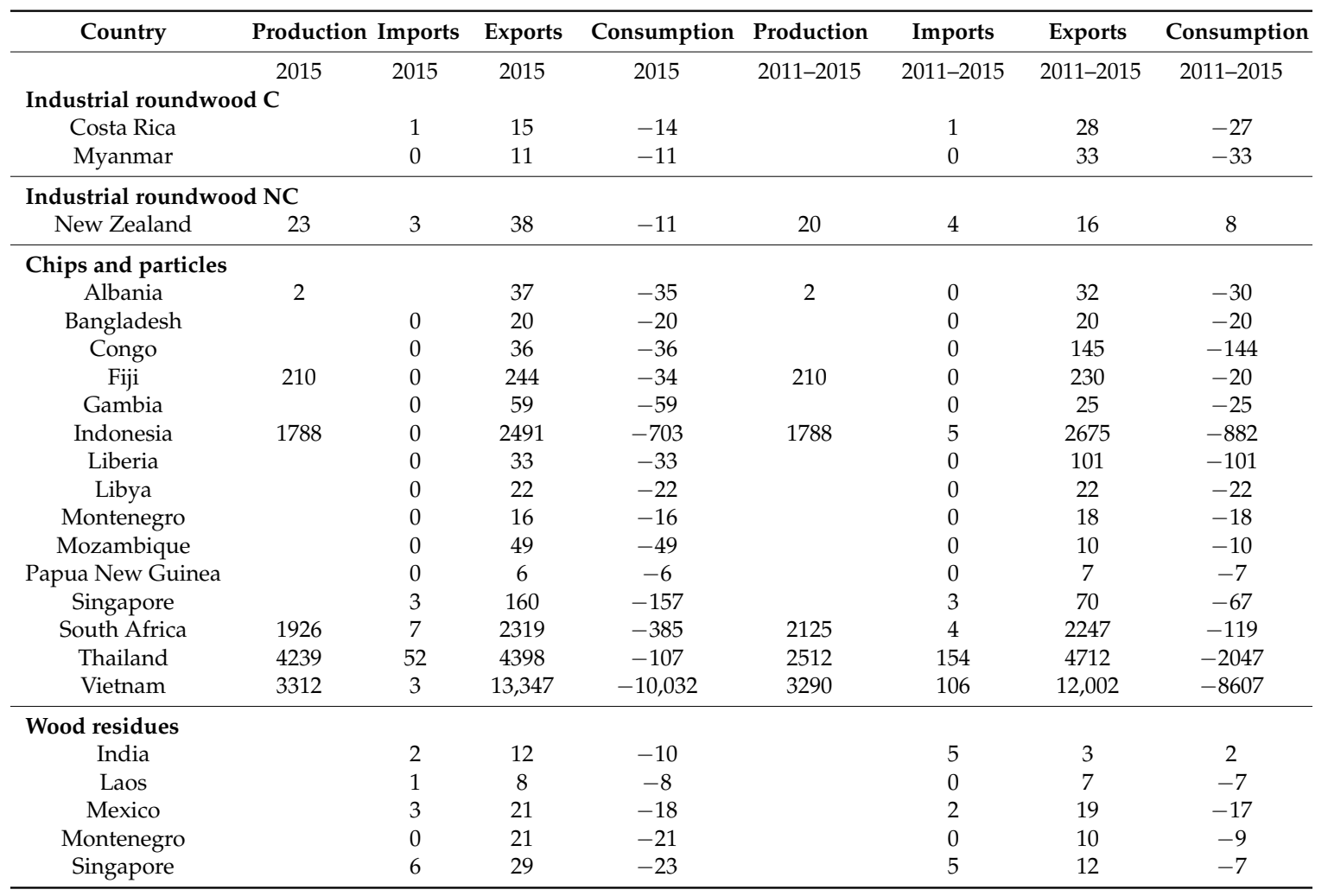

3.2. Test ii: Is the Production of Chips, Particles, and Wood Residues Consistent with the Production of Solidwood Products?

Table 4 shows the countries where the supply of forest industry by-products (chips, particles, and wood residues) is reported to exceed the production of solid wood products in 2015. It also gives the respective production figures and resulting average theoretical wood input coefficient per unit of solid wood products produced.

For some countries, particularly for Australia, the test for "chips and particles" production, which requires that "production of chips and particles < production of plywood + sawnwood" (column C compared with column D in Table 4) suggests that this data might be wrong. While often the entries related to suspicious data on chips and particles production is rated 'unofficial', that is not the case with Australia. Also, for example, Italy and the Netherlands report very high outputs of chips and particles compared to the production of solid wood products. To justify the figures, the activities in carpentry and other further processing of wood that would provide chips and particles must be of considerable magnitude.

The total output of chips, particles, and wood residues is very high compared to the reported production of solid wood products in France and Thailand. Notably, Thailand seems to have conflicting problems with the data on chips and particles production. Test ii suggests that the production is too high compared to the production of solid wood products. Yet, test i proposed that the production 
is too low to cover the reported exports. For France to reach the almost $18 \mathrm{Mm}^{3}$ difference between the production of final output and by-products (column F in Table 4), its volume of activities related to further processing of wood to furniture and other products must be considerable in order for the figures to be credible. For some countries where the resulting figure for "log use coefficient" is closer to 2, such as in Brazil or Finland, the data may be realistic, because these countries also produce plywood, which can require higher wood input than sawnwood. For instance, in Finland, the log input in sawnwood production is closer to 2 , and the use of sawlogs in plywood production is about $2.5 \mathrm{~m}^{3} / \mathrm{m}^{3}$, which means that somewhat high amounts of residues can be obtained as side-product. Also, in Sweden, the calculated log use of $2.1 \mathrm{~m}^{3}$ per one cubic meter of solid wood products could be realistic considering that the use of wood input in sawnwood production is rather high in Sweden and that by-products are additionally obtained from further processing.

Within a wider period of 2011-2016, considerable data problems can be detected (e.g., for Canada, which is not among the countries shown in Table 4 focusing on the year 2015).

Table 4. Production of solid wood products (column C), chips and particles (D), and wood residues (E), their difference $(\mathrm{F})$, and the resulting coefficient of wood use per solid wood product output (G, sum of all outputs divided by the solid wood output) in year 2015. The countries are ranked according to the value in column $(\mathrm{F})$.

\begin{tabular}{|c|c|c|c|c|c|c|c|}
\hline \multirow{3}{*}{ Country } & A & B & $C=a+B$ & D & $\mathbf{E}$ & $\mathbf{F}=\mathrm{C}-\mathrm{D}-\mathrm{E}$ & $G=(C+D+E) / C$ \\
\hline & Sawn-Wood & $\begin{array}{l}\text { Veneer and } \\
\text { Plywood }\end{array}$ & $\begin{array}{l}\text { Solid Wood } \\
\text { Products }\end{array}$ & $\begin{array}{l}\text { Chips and } \\
\text { Particles }\end{array}$ & $\begin{array}{c}\text { Wood } \\
\text { Residues }\end{array}$ & Difference & $\begin{array}{l}\text { Logs Use } \\
\text { Coefficient }\end{array}$ \\
\hline & $1000 \mathrm{~m}^{3}$ & $1000 \mathrm{~m}^{3}$ & $1000 \mathrm{~m}^{3}$ & $1000 \mathrm{~m}^{3}$ & $1000 \mathrm{~m}^{3}$ & $1000 \mathrm{~m}^{3}$ & $\mathrm{~m}^{3} / \mathrm{m}^{3}$ \\
\hline France & 7514 & 367 & 7881 & 5740 & 19,920 & $-17,779$ & 4.26 \\
\hline Brazil & 14,797 & 3829 & 18,626 & 11,788 & 19,140 & $-12,302$ & 2.66 \\
\hline Australia & 5085 & 296 & 5381 & 13,962 & 2577 & $-11,158$ & 4.07 \\
\hline Thailand & 2850 & 305 & 3155 & 4239 & 8200 & -9284 & 4.94 \\
\hline Poland & 4835 & 445 & 5280 & 3178 & 6500 & -4398 & 2.83 \\
\hline Italy & 1470 & 446 & 1916 & 4800 & & -2884 & 3.51 \\
\hline Portugal & 1134 & 80 & 1214 & 1275 & 2331 & -2392 & 3.97 \\
\hline Chile & 8372 & 1494 & 9866 & 10,208 & 1916 & -2257 & 2.23 \\
\hline Sweden & 18,174 & 95 & 18,269 & 9965 & 10,175 & -1871 & 2.10 \\
\hline Finland & 10,640 & 1207 & 11,847 & 8341 & 5314 & -1807 & 2.15 \\
\hline Netherlands & 185 & & 185 & 899 & 808 & -1522 & 10.22 \\
\hline Estonia & 1770 & 164 & 1935 & 1870 & 1155 & -1090 & 2.56 \\
\hline Spain & 2453 & 489 & 2942 & 1856 & 1846 & -760 & 2.26 \\
\hline Mali & 130 & 27 & 157 & 480 & 400 & -723 & 6.61 \\
\hline Lithuania & 1248 & 111 & 1359 & 1162 & 774 & -577 & 2.42 \\
\hline Sudan & 11 & & 11 & 383 & 106 & -478 & 45.45 \\
\hline Luxembourg & 78 & & 78 & 422 & 99 & -443 & 7.65 \\
\hline El Salvador & 16 & & 16 & & 457 & -441 & 29.04 \\
\hline South Africa & 1966 & 97 & 2063 & 1926 & 450 & -314 & 2.15 \\
\hline Latvia & 3479 & 280 & 3759 & 2513 & 1549 & -303 & 2.08 \\
\hline Slovenia & 725 & 98 & 823 & 300 & 800 & -277 & 2.34 \\
\hline Fiji & 130 & 20 & 150 & 210 & & -60 & 2.40 \\
\hline Colombia & 450 & 55 & 505 & 194 & 354 & -43 & 2.08 \\
\hline Georgia & 76 & 5 & 81 & & 121 & -40 & 2.49 \\
\hline Nicaragua & 62 & & 62 & & 80 & -18 & 2.29 \\
\hline Uruguay & 487 & 218 & 705 & 716 & 4 & -15 & 2.02 \\
\hline
\end{tabular}

3.3. Test iii: Can the Apparent Wood Consumption Levels Sustain the Reported Production of Forest Industry Products

\subsubsection{Case of Sawlogs and Veneer Logs Use to Production of Sawnwood, Plywood, and Veneer}

Table 5 displays the deficit of sawlogs and veneer logs reported in the data for the period of 2011-2015 for countries with such deficits being larger than 50,000 $\mathrm{m}^{3}$ in 2015. The table also gives the theoretically maximal apparent logs input $\left(\mathrm{m}^{3} / \mathrm{m}^{3}\right)$ for the reported solid wood production. It can be regarded to be maximal, because when calculating the deficit in the volume of logs used, it was generously assumed that all industrial roundwood imports but none of the exports are sawlogs and 
veneer logs. Dividing the trade volumes correctly to pulpwood, other industrial wood, and sawlogs and veneer logs would in no case increase the wood input coefficients but could make them lower.

In China, the deficit in logs availability is enormous: more than $160 \mathrm{Mm}^{3}$ in 2015 and 2016. The inconsistency in sawlogs and veneer logs use and supply has been increasing in recent years, when more and more industrial production has been reported in the statistics, while at the same time, a smaller increase in wood supply in the form of harvests or imports has been indicated. The figures propose that in 2015, at most $0.65 \mathrm{~m}^{3}$ of logs could have been used per $1 \mathrm{~m}^{3}$ of plywood and sawnwood produced in China. That is, of course, not realistic. Also, the data (e.g., for Vietnam and Venezuela) propose considerable problems yielding sawlog input well less than $1 \mathrm{~m}^{3} / \mathrm{m}^{3}$ in sawnwood and plywood production.

Table 5. Results from test iii for sawlogs and veneer logs. a deficit in a country is defined as "domestic harvests + imports of any industrial roundwood - minimum wood input required in production of sawnwood, plywood, and veneer" during 2011-2015, and the maximum log input coefficient in the solid wood production in 2015 is defined as "(domestic harvests of sawlogs and veneer logs + imports of any industrial roundwood)/(production of sawnwood, plywood and veneer)". Only countries that had a deficit of more than $50,000 \mathrm{~m}^{3}$ in 2015 are shown.

\begin{tabular}{|c|c|c|c|c|c|c|}
\hline \multirow{2}{*}{ Country } & 2011 & 2012 & 2013 & 2014 & 2015 & \multirow{2}{*}{$\begin{array}{c}2015 \\
\mathrm{~m}^{3} / \mathrm{m}^{3}\end{array}$} \\
\hline & & & $1000 \mathrm{~m}^{3}$ & & & \\
\hline China & $-63,974$ & $-100,756$ & $-103,770$ & $-133,028$ & $-161,330$ & 0.65 \\
\hline Vietnam & -5386 & -6061 & -6450 & -6642 & -7001 & 0.58 \\
\hline Turkey & -193 & 525 & -553 & -646 & -1773 & 1.28 \\
\hline Venezuela & -1093 & -1108 & -1031 & -1130 & -1135 & 0.31 \\
\hline Ecuador & -593 & -593 & -583 & -1008 & -586 & 1.03 \\
\hline Singapore & -540 & -532 & -539 & -534 & -535 & 0.05 \\
\hline Pakistan & -510 & -582 & -595 & -576 & -513 & 1.21 \\
\hline Bangladesh & -404 & -365 & -380 & -331 & -389 & 0.5 \\
\hline Kazakhstan & 82 & -1112 & -512 & -339 & -339 & 0.41 \\
\hline Philippines & -849 & -890 & -698 & -699 & -310 & 0.91 \\
\hline Kyrgyzstan & -120 & -138 & -153 & -162 & -177 & 0.08 \\
\hline Israel & -145 & -145 & -145 & -145 & -146 & 0.16 \\
\hline Mozambique & -47 & -22 & -20 & -110 & -122 & 1.2 \\
\hline Ethiopia & -132 & -131 & -111 & -122 & -115 & 0.33 \\
\hline Montenegro & 89 & 16 & -10 & -47 & -105 & 1.01 \\
\hline Jamaica & -97 & -95 & -52 & -92 & -93 & 0.1 \\
\hline Sri Lanka & -74 & -73 & -74 & -67 & -72 & 0.5 \\
\hline Benin & 40 & 27 & -141 & -74 & -71 & 0.98 \\
\hline Honduras & 86 & -40 & 63 & -2 & -53 & 1.34 \\
\hline
\end{tabular}

\subsubsection{Case of Pulpwood Use to Pulp Production}

Compared to the test made with sawlog using industries, the test on pulp production adds only some new regions into the set of countries with data problems. New countries in addition to those in Table 5 that enter the set with a higher than $50,000 \mathrm{~m}^{3}$ deficit in reported pulpwood availability with respect to the reported pulp supply in 2015 include Iran $\left(-270,000 \mathrm{~m}^{3}\right)$ and Bangladesh $\left(-65,000 \mathrm{~m}^{3}\right)$.

\subsubsection{Case of Wood Use in All Forest Industry Production}

Table 6 reports some results from the test including all forest industry products. More precisely, it shows the regions where the relatively loosely defined deficit in wood availability exceeds $50,000 \mathrm{~m}^{3}$ in 2015. Compared to the sawlog case of Table 5, the new entrants with data problems include, in particular, Iran, Malaysia, Romania, Ukraine, and Thailand, with a more than $1 \mathrm{Mm}^{3}$ deficit in wood availability with respect to their forest industry production. The wood quantity available to forest 
industry production (cubic meters of wood per 1 tonne of pulp or 1 cubic meter of other forest industry products) is often unrealistic and below 1.

Table 6. Results from test iii for all wood. a deficit of wood is defined as "domestic production or harvests of wood + imports - exports - wood input needed in the forest industry" during 2011-2015, and the maximum wood input coefficient in forest industry production is defined as "(amount of wood available)/(production of pulp and mechanical forest industry products)". Only countries with a deficit of wood exceeding 50,000 $\mathrm{m}^{3}$ in 2015 are shown. Only negative entries are shown.

\begin{tabular}{|c|c|c|c|c|c|c|}
\hline \multirow{2}{*}{ Country } & 2011 & 2012 & 2013 & 2014 & 2015 & Average Wood Input, 2015 \\
\hline & \multicolumn{5}{|c|}{$\left(1000 \mathrm{~m}^{3}\right)$} & $\mathrm{m}^{3} /$ output unit \\
\hline China & $-77,889$ & $-116,630$ & $-109,209$ & $-143,868$ & $-165,688$ & 0.77 \\
\hline Vietnam & $-11,098$ & $-12,451$ & $-14,668$ & $-14,442$ & $-15,854$ & -0.34 \\
\hline Romania & -1613 & -1761 & -4022 & -2950 & -4636 & 0.9 \\
\hline Malaysia & -1835 & -1285 & -3379 & -2302 & -3040 & 1.09 \\
\hline Ukraine & -875 & -1225 & -1489 & -1507 & -2310 & 0.85 \\
\hline Iran & -1087 & -1215 & -1380 & -1529 & -1556 & 0.19 \\
\hline Thailand & -3492 & -3862 & -3073 & -2661 & -1021 & 1.07 \\
\hline Venezuela & -1042 & -962 & -967 & -1143 & -860 & 0.72 \\
\hline Singapore & -553 & -540 & -554 & -736 & -728 & -0.43 \\
\hline Pakistan & -712 & -786 & -796 & -778 & -715 & 1.11 \\
\hline Mozambique & -286 & -352 & -374 & -824 & -708 & -0.24 \\
\hline Mexico & -574 & -872 & -652 & -629 & -603 & 1.32 \\
\hline Ecuador & -406 & -539 & -566 & -1087 & -512 & 1.07 \\
\hline Bangladesh & -498 & -459 & -473 & -433 & -488 & 0.43 \\
\hline Kazakhstan & & -1427 & -703 & -406 & -407 & 0.35 \\
\hline Montenegro & & -25 & -106 & -169 & -235 & 0.41 \\
\hline Cuba & -216 & -215 & -215 & -215 & -228 & 0.56 \\
\hline Sri Lanka & -230 & -227 & -227 & -220 & -225 & 0.15 \\
\hline Benin & -202 & -235 & -378 & -428 & -223 & -0.14 \\
\hline Kyrgyzstan & -115 & -133 & -148 & -157 & -172 & 0.12 \\
\hline Israel & -147 & -149 & -149 & -148 & -150 & 0.22 \\
\hline Ethiopia & -125 & -124 & -104 & -114 & -108 & 0.52 \\
\hline Greece & -706 & & -119 & -137 & -106 & 0.91 \\
\hline Jamaica & -97 & -95 & -52 & -92 & -93 & 0.1 \\
\hline $\begin{array}{l}\text { Congo Dem. } \\
\text { Republic }\end{array}$ & -437 & -415 & -55 & -59 & -78 & 1 \\
\hline Togo & -84 & -117 & -98 & -138 & -71 & 0.07 \\
\hline Slovenia & -120 & -201 & -146 & & -60 & 1.41 \\
\hline Honduras & & -38 & & -4 & -53 & 1.34 \\
\hline
\end{tabular}

\subsection{Results of the Test Using Linear Programming}

Table 7 shows the volume of industrial roundwood harvests or imports that is missing from the reported roundwood supply quantity according to the LP test given that the forest industry production data are correct. Alternatively, the forest industry production quantities may be reported to be too high. Only the countries where the inconsistency (deficit) between wood availability and need is suggested to be more than $50,000 \mathrm{~m}^{3}$ in any year during 2007-2016 are listed in Table 7. During the years of that period, the test finds 33-43 countries out of the 244 that had a deficit of more than $50,000 \mathrm{~m}^{3}$, 13-20 countries with a deficit of more than $500,000 \mathrm{~m}^{3}$, and 7-15 countries with a deficit of more than 1 million $\mathrm{m}^{3}$.

Largely, the countries found to have data problems in the form of too small wood supply with respect to the forest industry production are those identified already by the test iii earlier. Such countries include China, Iran, Malaysia, Mexico, Romania, Thailand, Turkey, Ukraine, Venezuela, and Vietnam. Very high deficits are found in particular in China and Vietnam. Nevertheless, the LP test indicates that countries such as Canada, India, Italy, Japan, New Zealand, and South Africa also show a deficit 
of roundwood use of more than $1 \mathrm{Mm}^{3}$ in recent years. The test also suggests considerable data problems for Germany for some years. Also, the deficits of much less than $1 \mathrm{Mm}^{3}$ can be considered to be of important magnitude, in particular, when compared to the roundwood harvests in a country. In the Supplementary Materials (Supplementary File S3: Additional results from the tests (excel-file)), we provide more results on the deficits indicated by this test.

Table 8 shows the surplus of the reported roundwood supply (harvests and net imports) compared to the wood needed for the reported forest industry production according to the LP test. Only the countries where the inconsistency (surplus) between wood availability and need in the forest industry is suggested to be more than $50,000 \mathrm{~m}^{3}$ in any year during 2007-2016 are listed. During the years of that period, the test finds $29-37$ countries out of the 244 that had a surplus of more than $50,000 \mathrm{~m}^{3}$, 10-15 countries with a surplus of more than $500,000 \mathrm{~m}^{3}$, and $8-10$ countries with a surplus of more than 1 million $\mathrm{m}^{3}$.

The countries where, in particular, the sawlog and veneer logs supply is very large compared to the exports and potential need in the local forest industry include, for instance, Brazil, Canada, India, Indonesia, and Russia. To match the wood use to wood supply in these regions would require unrealistically high log input coefficients in sawnwood or plywood production. In India, for instance, the reported harvests of sawlogs were closer to $48 \mathrm{Mm}^{3}$ in 2015, while the reported exports of all industrial roundwood were less than $20,000 \mathrm{~m}^{3}$. The quantity remaining in the local use is high considering the reported output of solid wood products of less than $10 \mathrm{Mm}^{3}$. As can be noted, some countries show both deficit (Table 7) and surplus (Table 8) in the wood supply with respect to the apparent demand for wood. This is because the tables report total quantities of roundwood. For example, in Vietnam, the proposed surplus concerns non-coniferous pulpwood, while the deficit is mainly sawlogs and veneer logs. For Canada and India, it is the opposite. The divisions by wood categories are provided in the Supplementary File S3: Additional results from the tests (excel-file).

Table 7. Deficit in industrial roundwood supply (harvests + net imports) according to the LP test $\left(1000 \mathrm{~m}^{3}\right)$, if the forest industry production data are correct. Only countries where the deficit is suggested to exceed $50,000 \mathrm{~m}^{3}$ in any of the years 2007-2016 are listed. Entries less than 50,000 $\mathrm{m}^{3}$ are not shown.

\begin{tabular}{|c|c|c|c|c|c|c|c|c|c|c|}
\hline Country & 2007 & 2008 & 2009 & 2010 & 2011 & 2012 & 2013 & 2014 & 2015 & 2016 \\
\hline Algeria & & & 56 & & & & & & & \\
\hline Bangladesh & 481 & 481 & 481 & 464 & 475 & 436 & 450 & 410 & 466 & 379 \\
\hline Belarus & 133 & 133 & 395 & 418 & 439 & & & & & 341 \\
\hline Benin & & & & & & & 125 & 61 & 58 & 58 \\
\hline Bulgaria & 276 & & & & & 152 & & 258 & & \\
\hline Cambodia & 180 & 107 & 93 & & & & & & & \\
\hline Cameroon & & & & & & 321 & & & & \\
\hline Canada & & & & & & & 3929 & 3715 & 1792 & 3072 \\
\hline China & 38,858 & 35,876 & 31,147 & 36,004 & 72017 & 109,120 & 114,238 & 145,016 & 174,350 & 170,933 \\
\hline Colombia & 111 & & & & & & & & & \\
\hline Costa Rica & & & & & & & & & 60 & 63 \\
\hline Cote d'Ivoire & & 317 & 306 & & & & & & & \\
\hline Cuba & 192 & 224 & 227 & 206 & 207 & 207 & 208 & 208 & 220 & 221 \\
\hline Denmark & & 176 & 357 & 202 & & 87 & & & & \\
\hline Dominican Republic & 71 & & & & & & & & & \\
\hline Ecuador & 563 & 514 & 555 & 668 & 668 & 667 & 658 & 1053 & 659 & 659 \\
\hline Egypt & & & & & & 51 & 68 & 82 & & 64 \\
\hline Ethiopia & 145 & 144 & 145 & 148 & 144 & 143 & 123 & 134 & 127 & 145 \\
\hline Georgia & & & & & & 63 & & & & \\
\hline Germany & 6935 & 10,896 & 5595 & & & 138 & & & & \\
\hline Ghana & 413 & 95 & 224 & 200 & 182 & 197 & & & & \\
\hline Greece & 880 & & 979 & 999 & 1001 & 289 & 305 & 314 & 299 & 299 \\
\hline Guatemala & 95 & 105 & & & & & & & & \\
\hline Honduras & & & & & & & & & & 482 \\
\hline India & 1829 & 1809 & 1057 & 1142 & 82 & & 392 & 1616 & 3153 & 3418 \\
\hline Iran & 1746 & 1858 & 1241 & 1540 & 2006 & 2043 & 2244 & 2445 & 3351 & 3946 \\
\hline
\end{tabular}


Table 7. Cont

\begin{tabular}{|c|c|c|c|c|c|c|c|c|c|c|}
\hline Country & 2007 & 2008 & 2009 & 2010 & 2011 & 2012 & 2013 & 2014 & 2015 & 2016 \\
\hline Israel & 231 & 166 & 167 & 168 & 165 & 165 & 165 & 164 & 165 & 165 \\
\hline Italy & 1285 & 1560 & 442 & & 356 & 831 & 236 & 737 & 1321 & 1757 \\
\hline Jamaica & 90 & 89 & 88 & 85 & 90 & 88 & 84 & 88 & 88 & 87 \\
\hline Japan & 2675 & 2153 & 758 & 55 & & 927 & 973 & 934 & 977 & 1000 \\
\hline Kazakhstan & & & 113 & 258 & 156 & 1486 & 756 & 412 & 413 & 413 \\
\hline Kyrgyzstan & 65 & 68 & 105 & 105 & 112 & 131 & 148 & 156 & 171 & 162 \\
\hline Latvia & & & & 135 & 60 & & 65 & & & \\
\hline Lebanon & & & & & & & 61 & & & 62 \\
\hline Luxembourg & 160 & 161 & 89 & & & 248 & & 182 & 159 & 175 \\
\hline Malaysia & 2365 & & & 265 & & & 603 & & 1701 & 2723 \\
\hline Mexico & 737 & 789 & 1022 & 1401 & 1211 & 1471 & 1363 & 1272 & 1351 & 1364 \\
\hline Mongolia & 387 & 390 & 390 & 393 & 393 & & & & & \\
\hline Montenegro & & & & & & & 143 & 155 & 191 & 91 \\
\hline Morocco & 54 & & 418 & 324 & 315 & 299 & 445 & & & \\
\hline Mozambique & & & & 56 & & & & 81 & 94 & 71 \\
\hline Myanmar & 116 & 116 & 116 & 123 & 116 & 116 & 683 & 116 & 116 & 116 \\
\hline Netherlands & & & & 79 & & & & & & \\
\hline New Zealand & 1422 & 1801 & 733 & 1018 & 1489 & 1461 & 958 & 950 & 1472 & 1890 \\
\hline Nigeria & 77 & 71 & 77 & 77 & 76 & 71 & 75 & 92 & 92 & 93 \\
\hline Norway & & & 707 & & & & & & & \\
\hline Pakistan & 640 & 662 & 767 & 802 & 820 & 892 & 905 & 887 & 823 & 760 \\
\hline Papua NewGuinea & & & & & & & & & & 61 \\
\hline Philippines & 702 & 775 & 769 & 1697 & 1338 & 896 & 676 & 668 & 313 & 378 \\
\hline Portugal & & 80 & 358 & & & & & & & \\
\hline Romania & & 61 & & & & 1570 & 4057 & 2879 & 5389 & 4877 \\
\hline Serbia & & & & & & & & 56 & & \\
\hline Serbia Montenegro & 75 & 95 & 82 & & 63 & 60 & 70 & 67 & & \\
\hline Singapore & 604 & 603 & 607 & 602 & 607 & 596 & 603 & 602 & 604 & 608 \\
\hline Slovenia & 258 & 234 & & & & & & & & \\
\hline South Africa & & & & 188 & & 70 & & 931 & 1299 & 2261 \\
\hline South Korea & & & 299 & & & & & 784 & & \\
\hline Sri Lanka & 56 & 293 & 296 & 292 & 295 & 295 & 295 & 288 & 293 & 293 \\
\hline Switzerland & 639 & 136 & 178 & 212 & 357 & & & & & \\
\hline Thailand & & 150 & 1827 & 2967 & 3011 & 3004 & 3171 & 3439 & 3152 & 2998 \\
\hline Tunisia & & 60 & 58 & 58 & 62 & & & & & \\
\hline Turkey & 135 & & & & & & 198 & 259 & 1132 & 2276 \\
\hline Ukraine & 702 & 621 & 275 & 203 & 506 & 1258 & 1241 & 1646 & 1634 & 1634 \\
\hline UnitedStates & & & & & & & & 679 & & \\
\hline Venezuela & 320 & 238 & 110 & 903 & 1012 & 1027 & 950 & 1050 & 1054 & 1054 \\
\hline Vietnam & 3985 & 3987 & 4351 & 4986 & 5329 & 5980 & 6472 & 6747 & 7111 & 7266 \\
\hline Zimbabwe & 96 & 95 & 55 & & & & & & & \\
\hline
\end{tabular}

Table 8. Surplus of industrial roundwood supply (harvests + net imports), if the forest industry production data are correct. Results from the LP test. Only countries where the surplus is more than $50,000 \mathrm{~m}^{3}$ in any of the years 2007-2016 are listed. Entries less than 50,000 $\mathrm{m}^{3}$ are not shown.

\begin{tabular}{|c|c|c|c|c|c|c|c|c|c|c|}
\hline Country & 2007 & 2008 & 2009 & 2010 & 2011 & 2012 & 2013 & 2014 & 2015 & 2016 \\
\hline Angola & & & & & & & 50 & 53 & 66 & \\
\hline Argentina & & & & 439 & & & & & & 197 \\
\hline Australia & 4302 & 3639 & 3718 & 2205 & 2946 & 1440 & 248 & 1294 & 1891 & 1832 \\
\hline Belarus & & & & & & 466 & 195 & & & \\
\hline Bhutan & 70 & 51 & & & & & & & & \\
\hline $\begin{array}{l}\text { Bosnia and } \\
\text { Herzegovina }\end{array}$ & & & & & & & 296 & 121 & 122 & 119 \\
\hline Brazil & & & & & 3432 & 13,379 & 13,930 & 10,353 & 4693 & 4890 \\
\hline Burkina Faso & 57 & 57 & 58 & 60 & 60 & 59 & 59 & 60 & 60 & 60 \\
\hline Burundi & 101 & 101 & 101 & 101 & 101 & 215 & 211 & 225 & 225 & 225 \\
\hline Canada & 3995 & 3269 & 2665 & 8398 & 12,117 & 7472 & 9142 & 8639 & 1917 & 1338 \\
\hline Central African Rep. & 214 & 203 & 68 & 51 & 123 & 116 & 95 & & 114 & 106 \\
\hline Congo & 476 & 547 & 428 & 426 & 198 & 239 & 72 & & & \\
\hline
\end{tabular}


Table 8. Cont.

\begin{tabular}{|c|c|c|c|c|c|c|c|c|c|c|}
\hline Country & 2007 & 2008 & 2009 & 2010 & 2011 & 2012 & 2013 & 2014 & 2015 & 2016 \\
\hline Croatia & 294 & 393 & 442 & 410 & 701 & 1011 & 396 & 100 & 184 & 164 \\
\hline El Salvador & 621 & 614 & 618 & 617 & 617 & 617 & 632 & 630 & 628 & 630 \\
\hline Equatorial Guinea & & 194 & 450 & & & & & & & \\
\hline Fiji & 231 & 200 & 206 & 419 & 414 & 413 & 380 & 379 & 409 & 409 \\
\hline Gambia & 103 & 103 & 103 & 103 & 103 & 103 & 104 & 106 & 107 & \\
\hline Greece & 469 & 469 & & & & 475 & 51 & & & \\
\hline Guatemala & 131 & 73 & 101 & 189 & 320 & & 118 & & & \\
\hline Guyana & & 100 & 124 & 137 & 149 & 157 & 122 & 68 & & 97 \\
\hline Haiti & 192 & 192 & 192 & 192 & 192 & 192 & 192 & 192 & 192 & 192 \\
\hline Hungary & & 594 & 406 & & & & & & & \\
\hline India & 20,642 & 21,343 & 20,939 & 21,676 & 22,399 & 22,399 & 22,406 & 22,401 & 22,401 & 22,385 \\
\hline Indonesia & & 2176 & & & & & 8511 & 8486 & 8494 & 8536 \\
\hline Iran & 166 & 171 & 156 & 149 & 172 & 192 & 199 & 185 & 120 & 91 \\
\hline Kenya & 79 & 70 & 411 & 412 & 409 & 131 & 104 & 121 & 130 & 132 \\
\hline Laos & & & & & & & & 136 & 354 & 354 \\
\hline Liberia & & & & 91 & & & & & & \\
\hline Macedonia & 72 & 129 & 78 & 66 & 89 & 85 & 88 & 92 & 103 & 104 \\
\hline Madagascar & 180 & 124 & 60 & 95 & 98 & 99 & & & & \\
\hline Montenegro & 70 & 111 & 74 & 74 & & & 53 & & & \\
\hline Nigeria & 1853 & 1860 & 1866 & 1814 & 1817 & 1815 & 1796 & 1845 & 1778 & 2010 \\
\hline Panama & & 61 & 96 & & & & & & & \\
\hline Papua New Guinea & & & 314 & 1178 & & & 247 & 253 & & \\
\hline Paraguay & 1631 & 1629 & 1631 & 1628 & 1635 & 1631 & 1628 & 1631 & 1629 & 1629 \\
\hline Philippines & & & & & & 74 & 473 & 410 & 350 & 308 \\
\hline Poland & 3971 & 3575 & 2758 & 1657 & 1545 & 2144 & 1233 & 1637 & 1679 & 2042 \\
\hline Portugal & 347 & 149 & 229 & 334 & & & & & & \\
\hline Romania & 282 & & & & & & & & & \\
\hline Russia & 5214 & & 7073 & 12,503 & 13,711 & 17,760 & 14,630 & 14,931 & 17,388 & 15,919 \\
\hline Rwanda & 54 & 670 & 651 & 651 & 651 & 651 & 651 & 651 & 651 & 651 \\
\hline Slovenia & & 117 & & & & & & & & \\
\hline Solomon Islands & & & & & & & & & 199 & 545 \\
\hline South Africa & & 403 & & & 399 & 938 & 649 & 80 & & \\
\hline Sudan & & & & & & 376 & 386 & 633 & 633 & 633 \\
\hline Swaziland & & & 52 & 530 & 607 & 613 & 593 & 545 & 525 & 439 \\
\hline Switzerland & & & 68 & & & & & & & \\
\hline Tanzania & 234 & 252 & 239 & 247 & 248 & 409 & 663 & 661 & 647 & 659 \\
\hline Trinidad and Tobago & & & & & & & & 85 & 85 & 85 \\
\hline Uganda & 1310 & 1409 & 1505 & 1621 & 1160 & 1166 & 1084 & 1074 & 1076 & 1071 \\
\hline Uruguay & 1222 & & & 289 & & & & & & \\
\hline Vietnam & & 312 & 324 & 340 & 222 & 273 & 287 & 150 & 321 & 353 \\
\hline
\end{tabular}

\section{Discussion}

The tests indicated several cases of data problems associated with the production of wood chips and particles and wood residues. Both cases of too little production (e.g., Vietnam) with respect to net exports and cases of suspiciously too much production with respect to mechanical wood processing (e.g., Australia, France) were observed. It is not surprising to find inconsistencies in these data though. It obviously takes an effort to collect reliable data even on production of the main mechanical forest industry products often produced in numerous small units. To get data on the related by-products is even more difficult. These data are also prone to measurement errors (converting loose cubic meters to solid cubic meters, etc.), if the quantities are measured, tracked, and reported at all.

While collecting reliable data on the residual side streams is a challenge, it would still be an important task to do. It would make it possible to model the production processes and material streams in the forest sector more accurately and that would lead to improved estimates for wood use coefficients, if the FAOSTAT data are used as a basis for estimating them. The wood residues are partly substitutes to roundwood, in particular, pulpwood in the production of pulp and panels. If some supply of residues is missing from the statistics, or if the supply is exaggerated, the demand for pulpwood can be projected to be higher/lower than it should be in forest sector model simulations. Good data 
on wooden side-streams would also make it possible to examine and compare the availability and cascading uses of wood biomass in a more reliable manner.

It is notably more difficult to identify cases where the industrial residues production is reported to be too low in the statistics. This is because the low figures are not always due to weak data quality, but also due to the inefficient collection and lack of further use of these residues or due to efficient use of sawlogs input (low input coefficient) in the sawnwood and plywood production.

Even very rough tests comparing the reported wood availability to forest industry production reveal severe data problems in several countries. It is not uncommon that the data suggest unrealistically that less than one cubic meter of woody material has been available per ton of pulp or cubic meter of other forest industry products. For instance, the data for China and Vietnam show large gaps between the apparent availability of sawlogs and the reported production of sawnwood and plywood. Data problems related to relationships of reported regional wood supply versus wood needed by the industry were found in many other countries as well. Canada, Germany, India, Iran, New Zealand, Romania, and Thailand are just a few examples of the countries where the inconsistency between the annual wood supply and use has been more than $1 \mathrm{Mm}^{3}$ at least in some years during the last decade. Using such inconsistent data without looking at the sources of the error and adjusting the data respectively will have wide impacts on the reliability of the analysis using the data.

The aim of this study was not to evaluate the sources behind the observed data problems, but they can be various. Negative apparent consumption of woody material points directly to the errors in data on production or trade of these materials. Data problems related to the relation of the amount of chips and particles with respect to the production of solid wood products can have their roots in errors in production data in either side. When the apparent consumption of wood is negative or when the apparent amount of wood reported available is not in credible proportion to the reported volumes of forest industry production, there may be data errors both in forest industry production or wood supply and trade. Also, such inconsistencies in the data may refer to illegal logging and non-documented (illegal) imports of wood. The reasons for the data problems can thus be rather case specific, and the data providers should have the best insight on the sources of errors.

Inconsistencies between the roundwood supply and its industrial use were found both in the form of deficits and surpluses of wood. In China alone, a gap between the annual use and supply of sawlogs and veneer logs has been over $160 \mathrm{Mm}^{3}$ in recent years. Data showing a considerable excess supply of roundwood on the market compared to its potential need as raw material in the forest industry was found, for instance, in India $\left(22 \mathrm{Mm}^{3}\right)$ and Russia $\left(16 \mathrm{Mm}^{3}\right)$. Errors and uncertainties of such magnitudes have important consequences to the results of any analysis using the data and thus call for special attention by the data users.

Several countries where the tests indicated too low wood supply with respect to the forest industry production or too high exports with respect to wood harvests have earlier been recognized to face problems of illegal logging or imports of illegally logged roundwood. In some of these regions, (e.g., China, Malaysia, Thailand, and Vietnam), the European Union is working on improving the situation via the Forest Law Enforcement, Governance, and Trade Action Plan [19]. In further work, it would be important to identify the reasons for the data problems and improve the statistical systems. Also, the part of illegal harvests and trade in roundwood should enter the wood streams analyzed in the forest sector models and analyses. Else, the results are biased.

Finally, it must be said that there is no guarantee that the data are correct if they pass the tests reported here. The tests made could only detect some cases of incorrect data. It could be useful for the data providers to adapt and further develop this kind of methodology for checking their data, if not used already.

\section{Conclusions}

While the FAOSTAT forestry data can be expected to be as reliable as possible in practice, the data tests in this study indicated severe problems related to the production and trade of wood products 
in several countries. a lack of reliable official data from some regions is obvious. As these freely available statistics provide valuable information for a wide range of businesses, media, policy making, and scientific analyses, it would be of utmost importance to further improve the data, despite the many challenges faced.

Meanwhile, when using the current FAOSTAT forestry data, one should, like with any data, be cautious. For instance, if wood input coefficients and demand functions for forest industry products employed in a forest sector model are calibrated to match these data while ignoring the inconsistencies in the data, the model results are doomed to carry on these errors in projections of future supply, demand, and prices of forest products. Likewise, the currently available data do not form a reliable basis for calculating the development of the stock of harvested wood products needed in carbon stock accounting for all countries.

Supplementary Materials: The following are available online at http:/ /www.mdpi.com/1999-4907/9/7/407/s1, Supplementary File S1: Data for reference input coefficients (excel-file), Supplementary File S2: Description of the LP model (word.doc), Supplementary File S3: Additional results from the tests (excel-file).

Author Contributions: A.M.I.K. was responsible for the problem formulation, data preparation, software used in the analysis, and the first analysis and draft preparation for the manuscript. B.S. participated in the analysis of the results and the co-writing of the manuscript and was also mainly responsible for funding acquisition.

Funding: The research leading to these results was funded by the forest sector modeling part of the research projects for FORMIT ("Forest Management for the Mitigation potential of European forests"- financed by the EU's 7th Research Program as project no. 311970) and POLYFORES ("Decision-making Support for Forest Ecosystem Services in Europe-Value Assessment, Synergy Effects and Trade-offs", financed by the EU's program FP7 ERA_NET Sumforest).

Conflicts of Interest: The authors declare no conflict of interest.

\section{References}

1. The FAO's Forest Product Statistics (FAOSTAT). Forestry Production and Trade. Available online: http://www.fao.org/faostat/en/\#data/FO (accessed on 5 April 2018).

2. Buongiorno, J.; Shushuai, Z.; Zhang, D.; Turner, J.A.; Tomberlin, D. The Global Forest Products Model (GFPM): Structure, Estimation, and Applications; Academic Press: San Diego, CA, USA, 2003; p. 301.

3. Kallio, A.M.I.; Moiseyev, A.; Solberg, B. The Global Forest Sector Model EFI-GTM-The Model Structure. Available online: http:/ / www2.efi.int/portal/virtual_library/publications/technical_reports / 15/ (accessed on 5 April 2018).

4. Havlík, P.; Schneider, U.A.; Schmid, E.; Bottcher, H.; Fritz, S.; Skalsky, R.; Aoki, K.; De Cara, S.; Kindermann, G.; Kraxner, F.; et al. Global land-use implications of first and second generation biofuels targets. Energy Policy 2011, 39, 5690-5702. [CrossRef]

5. Jonsson, R. Econometric Modelling and Projections of Wood Products Demand, Supply and Trade in Europe. Geneva Timber and Forest Discussion Paper 59. 2012, p. 1. Available online: https://www.slu. se/globalassets / ew/org/centrb / f-for/pdf/econometricmodellingandprojectionsof-woodproducts.pdf (accessed on 7 April 2018).

6. Hurmekoski, E.; Hetemäki, L.; Linden, M. Factors affecting sawnwood consumption in Europe. For. Policy Econ. 2015, 50, 236-248. [CrossRef]

7. Brunet-Navarro, P.; Jochheim, H.; Kroiher, F.; Muys, B. Effect of cascade use on the carbon balance of the German and European wood sectors. J. Clean. Prod. 2018, 170, 137-146. [CrossRef]

8. Schyns, J.F.; Booij, M.J.; Hoekstra, A.Y. The water footprint of wood for lumber, pulp, paper, fuel and firewood. Adv. Water Resour. 2017, 107, 490-501. [CrossRef]

9. O'Brien, M.; Bringezu, S. European Timber Consumption: Developing a Method to Account for Timber Flows and the EU's Global Forest Footprint. Ecol. Econ. 2018, 147, 322-332. [CrossRef]

10. Mills Busa, J.H. Deforestation beyond borders: Addressing the disparity between production and consumption of global resources. Conserv. Lett. 2013, 6, 192-199. [CrossRef] 
11. The Intergovernmental Panel on Climate Change (IPCC). Datasets for use in the IPCC Guidelines FAO Data and How It Can Be Used in the IPCC Agriculture and Land Use Guidelines. Available online: https:/ / www.ipcc-nggip.iges.or.jp/public/mtdocs/pdfiles/0910_FAO-IFAD-IPCC-Meetingreport.pdf (accessed on 5 April 2018).

12. Kallio, A.M.I.; Solberg, B.; Käär, L.; Päivinen, R. Economic impacts of setting reference levels for the forest carbon sinks in the EU on the European forest sector. For. Policy Econ. 2018, 92, 193-201. [CrossRef]

13. The United Nations Economic Commission for Europe; The Food and Agriculture Organization of the United Nations (UNECE-FAO). Complete Database, all Years, all Products. Data for 1964-2016. Available online: https: / /www.unece.org/forests/fpm/onlinedata.html (accessed on 5 April 2018).

14. FAO. Pulp and Paper Production Capacities. Available online: http://www.fao.org/forestry/statistics/ 81757/en/ (accessed on 5 April 2018).

15. RISI. Available online: https://www.risiinfo.com/ (accessed on 3 October 2013).

16. UNECE. Forest Product Conversion Factors: Project Overview and Status. 2009. Available online: https: / / www.unece.org/fileadmin/DAM/timber/meetings/forest-products-conversion-factors.pdf (accessed on 5 April 2018).

17. UNECE and FAO. National wood resource balances. In Proceedings of the Geneva Timber and Forest Discussion Papers 53, Geneva, Switzerland, 31 March-1 April 2008.

18. UNECE. Forest Product Conversion Factors for the UNECE Region. Geneva Timber and Forest Discussion Papers 49. Available online: https:/ / www.unece.org/fileadmin/DAM/timber/publications/DP-49.pdf (accessed on 5 April 2018).

19. EU FLEGT Facility. Available online: http:/ / www.euflegt.efi.int/flegt-action-plan (accessed on 5 April 2018).

(C) 2018 by the authors. Licensee MDPI, Basel, Switzerland. This article is an open access article distributed under the terms and conditions of the Creative Commons Attribution (CC BY) license (http:/ / creativecommons.org/licenses/by/4.0/). 